\title{
Is our media (still) racist?
}

Herman Wasserman

The question requires more than a yes or no answer. If racism exists, it is certainly not for a lack of attempts to rid the media from the shackles of its history under apartheid. Since democracy arrived in South Africa, the media industry has undergone some wide-ranging changes. On the level of ownership and editorial changes, the industry has seen ownership of large media houses pass to black consortia and the appointment of black editors and journalists to previously white-dominated media institutions. On the level of professionalism, the system of self-regulation entered into has attempted to ensure that media content is rid of racist stereotyping. The Press Ombudsman's code cautions the media to "avoid discriminatory or denigrator references to people's race, colour, ethnicity, religion, gender, sexual orientation or preference, physical or mental disability or illness, or age", unless it "is strictly relevant to the matter reported or adds significantly to readers' understanding of that matter". It also warns against hate speech, as does the Broadcasting Complaints Commission of South Africa's code, based on the values enshrined in the Constitution.

So do we still need to think about racism in the South African media? A recent report by the Media Monitoring Project (MMP), 'Revealing Race', suggests we do. It points out that "despite innumerable changes, juniorisation of newsrooms and a lack of skilled staff and adequate resources have resulted in an increase in the number of incidents of poor reporting in South African media". "Media tend to lead with dramatic headlines that may sell more publications, but often trivialise the issues at stake and promote stereotypes and discrimination, which reinforces the alienation of specific groups of people". The report found that racism and coverage of racism and xenophobia often lacks analysis and context, and that the 'other' is often still stereotyped. This 'other' seems to increasingly be black foreign nationals.

As was pointed out by prof Guy Berger, this report raised much less furore than the one the MMP was comissioned to do by the Human Rights Commission in 1999/2000. That report, marred by questionable methodology, indicated a media that was still deeply scarred by the apartheid past. The new report suggests some improvement, but criticises the media especially as far as crime reporting is concerned, for what it sees as racist assumptions about the perpetrators of crime (read the report at www.mediamonitoring.org.za)

Yet again one could ask questions about the MMP's method, and how much is really 'revealed' about racism in the SA media. By measuring only articles that mention 'race' specifically (and over a relatively short period, but that is another issue), only the explicit manifestations of racism could be considered. Racism is a much more sly animal, and to catch it you need more sophisticated and diverse tools.

An especially important aspect that has been neglected in both the MMP studies thus far is the intersection of race and class. The media industry might have transformed its ownership and editorial staff to reflect the demography of the country, but is it also representative of different classes in society? Because the mainstream media operates as a business, it obeys market logic, which means that it has a bias towards lucrative audiences. Put simply, because the media sells audiences to advertisers, it has to sell news that those audiences are interested in. This would usually mean that, for instance, strike action will be covered from the perspective of business rather than from that of workers; events in urban centres will get 
preference before rural stories; lack of social delivery will be seen as a news story when there is a flare-up and roads are blocked but interest will wane when things return to the 'normal': the poor eking out a living far away from the glare of publicity.

\section{What does this have to do with race?}

South Africa is one of the most unequal countries in the world, and these inequalities still coincides largely with the racial divides of the apartheid past. For the media to contribute to a more non-racial society, it has to do more than avoid explicit racial stereotypes, racist hate speech or the linking of race with crime. It has to dare view the news from different perspectives, also giving the viewpoints of those sections of society whose voices are seldom heard because they are not an attractive market segment. To some extent the much-reviled tabloids, while often guilty of racism in the form of xenophobia (and singled out in the MMP report), have managed to turn the media market upside down exactly because they view the news from the perspective of the majority of working class, poor readers who are mostly shunned from mainstream media. Addressing racism from a structural point of view would also mean supporting initiatives to establish more community and local media that serve poorer communities. In other words, where the MMP study set out to look for racism where race and ethnicity were explicitly mentioned in news reports, racism is often present precisely where race and ethnicity is not mentioned. Where news coverage presents the point of view of a specific section of society yet does so under the pretext of innocently 'holding up a mirror to society'; where certain economic policies are presented as common sense and contesting views are omitted or ignored; where crime, poverty and social decay is presented as the result of individual negligence (the phenomenon of 'blaming the victim') rather than that of systemic failure - in these cases race is part of the picture exactly because it is invisible.

Getting to get to grips with racism in the media needs a holistic approach, and not only one that deals with the overt manifestations of the phenomenon. A disease also lurks there where its symptoms are not clearly seen.

Herman Wasserman teaches Media, Communication and Cultural Studies at Newcastle University, UK and is Associate Professor Extraordinary of Journalism at Stellenbosch University.

This article was first published in The Media (July 2007), pp. 32-33, and is reproduced here with the permission of the author and publisher. 